\title{
Effect of salt stress on lipid composition and membrane fluidity of the salt- tolerant yeast Zygosaccharomyces rouxii
}

\author{
KUNIAKI HOSONO*
}

Fermentation Research Institute, Agency of Industrial Science and Technology, MITI, 1-1-3 Higashi, Tsukuba 305, Japan

(Received 29 May 1991; revised 27 August 1991; accepted 3 October 1991)

\begin{abstract}
When the salt-tolerant yeast $Z$ ygosaccharomyces rouxii was grown in YPD medium containing $15 \%(\mathrm{w} / \mathrm{v}) \mathrm{NaCl}$, the relative amounts of $C_{16: 1}$ and $C_{18: 1}$ fatty acids in acyl lipids increased and those of $C_{18: 0}$ and $C_{18: 2}$ acids decreased both in whole cells and in crude plasma membrane preparations, as compared with cells grown in YPD medium alone. The proportions of $\mathrm{C}_{12: 0}$ and $\mathrm{C}_{14: 0}$ acids, which are minor components of yeast lipids, decreased in whole cells and markedly increased in plasma membranes when $15 \% \mathrm{NaCl}$ was included in the growth medium. The degree of unsaturation of fatty acids in the membranes and in whole cells decreased in the presence of $15 \% \mathrm{NaCl}$ in the culture medium. The amount of free ergosterol in the membranes of cells grown in $15 \% \mathrm{NaCl}$ increased to 2.9 times that of control cells. The ratio of ergosterol to phospholipid increased to 5 times that of control cells, whereas the ratio of phospholipid to protein in the membranes of cells grown in $15 \% \mathrm{NaCl}$ decreased to less than half that of control cells. The fluorescence polarization value of DPH (1,6-diphenyl-1,3,5-hexatriene) in membranes of cells grown in $15 \% \mathrm{NaCl}$ was 1.2 times higher than that for membranes from control cells, indicating a decrease in membrane fluidity in the presence of a high concentration of $\mathrm{NaCl}$.
\end{abstract}

\section{Introduction}

In most organisms that can grow at high osmotic pressure, low molecular mass substances are accumulated internally to equilibrate the cytoplasm osmotically with the surrounding medium (Yancey et al., 1982). Adjustment of the internal osmotic pressure with organic solutes has been reported for a wide range of microorganisms, including bacteria (Csonka, 1989), cyanobacteria (Reed et al., 1986; Hagemann et al., 1987), fungi (Gadd et al., 1984; Jennings, 1984; Hocking, 1986), algae (Ben-Amotz \& Avron, 1983) and yeasts (Adler et al., 1985; Meikle et al., 1988). Osmotically stressed yeasts accumulate osmoregulatory solutes such as glycerol and arabitol (Onishi, 1963). These neutral, low molecular mass compounds were thought to protect enzymes and structural proteins against inactivation, inhibition and denaturation, which would otherwise be brought about by low water activity (Brown, 1978).

Zygosaccharomyces rouxii is one of a small number of yeasts which can grow well in media of high osmolarity. The strain of $Z$. rouxii used in the present study can

\footnotetext{
* Tel. 298546042 ; fax 298546009.
}

Abbreviation: DPH, 1,6-diphenyl 1,3,5-hexatriene. tolerate a high concentration of $\mathrm{NaCl}$ (ca. $20 \%, w / v$; $3.4 \mathrm{M}$ ) in the growth medium whereas Saccharomyces cerevisiae cannot. This distinguishing property of osmotolerant yeasts has long been recognized (Edgley \& Brown, 1983; Reed et al., 1987), but the mechanism of osmotolerance has not been fully elucidated. However, several aspects of osmoregulation in bacteria have been reported. Le Rudulier et al. (1984) discussed the molecular biology of the osmotic tolerance genes that protect Escherichia coli against osmotic stress and which might work in a similar manner in plants and animals. Higgins et al. (1987) reviewed the transcription of the genes encoding the high-affinity $\mathrm{K}^{+}$and betaine transport systems of $E$. coli and Salmonella typhimurium, which are tightly regulated in response to osmotic stress.

The plasma membrane controls the entry of nutrients and the exit of waste products, and generates differences in their concentrations between the interior and exterior of the cell. It also acts as a sensor of external signals, allowing the cell to change in response to environmental cues. Biological membranes are generally thought of as a kind of two-dimensional solution of globular integral proteins dispersed in the fluid lipid matrix (Singer \& Nicolson, 1972). Membrane fluidity influences various important functions that take place in biological membranes. It is membrane lipids especially that play a 
crucial role in controlling membrane fluidity. Several factors are involved in the maintenance of proper fluidity: the type of fatty acyl chains, the amount of sterols and, to a lesser extent, the nature of the polar head-groups of phospholipids (Russell, 1989).

This paper describes a study of the changes in lipid composition of whole cells and crude plasma membranes when $Z$. rouxii was grown in medium with or without $15 \% \mathrm{NaCl}$. To determine changes in membrane fluidity, crude plasma membranes were labelled with a fluorescent probe and the fluorescence polarization was measured. From both chemical analyses and spectroscopic analysis, membrane fluidity was found to decrease when cells were grown in the presence of a high concentration of salt.

\section{Methods}

Yeast and growth conditions. Zygosaccharomyces rouxii IFO 1876 was maintained at $4{ }^{\circ} \mathrm{C}$ on slopes of YPD $(1 \%$, w/v, yeast extract, $2 \%, w / v$, peptone and $2 \%$, w/v, glucose, pH 5.0) agar with $15 \%$ (w/v) NaCl. The yeast was grown aerobically in YPD medium with or without $15 \%$ $\mathrm{NaCl}$ at $30^{\circ} \mathrm{C}$

Preparation of protoplasts and crude plasma membranes. Yeast cells were converted to protoplasts by a modified enzymic digestion of the cell wall as described previously (Hosono \& Hahn-Hägerdal, 1986). Cells grown in YPD medium with or without $15 \% \mathrm{NaCl}$ were harvested in the exponential phase by centrifugation and washed twice with $15 \% \mathrm{NaCl}$ or distilled water, respectively. Washed cells were resuspended in $1.0 \mathrm{M}$-sorbitol containing $25 \mathrm{~mm}$-EDTA and $2.5 \% 2-$ mercaptoethanol and incubated with slow stirring for $30 \mathrm{~min}$ at room temperature. The cells were then collected by centrifugation and washed twice with $1.0 \mathrm{M}$-sorbitol. Pelleted cells were resuspended at $5 \times 10^{9}$ cells ml-1 in protoplasting buffer $(1.0 \mathrm{M}$-sorbitol and $10 \mathrm{mM}-$ EDTA in $20 \mathrm{mM}$-Tris/ $\mathrm{HCl}$ buffer, pH 7.5). After addition of Zymolyase $20 \mathrm{~T}$ (ca. 0.5-1.0 mg ml-1 mixture was incubated with stirring at $30^{\circ} \mathrm{C}$ and formation of protoplasts was followed by phase contrast microscopy (ca. 30-60 min). Cells grown in $15 \% \mathrm{NaCl}$ were more easily converted to protoplasts than cells grown in YPD medium. After more than $90 \%$ of cells had been converted to protoplasts, the mixture was centrifuged at $2200 \mathrm{~g}$ for $10 \mathrm{~min}$ at room temperature. The pellet was resuspended in a small volume of $1.0 \mathrm{M}$-sorbitol and the viscous suspension was added to a 10fold volume of distilled water to osmotically lyse the protoplasts. To sediment plasma membranes the suspension was centrifuged at low speed $(2200 \mathrm{~g}, 10 \mathrm{~min})$. The membranes were washed by resuspension in distilled water and recentrifugation until the supernatant reached an optical density of less than 0.01 at $660 \mathrm{~nm}$. Cross-contamination of plasma membrane preparations was monitored by measuring the specific activity of the mitochondrial marker enzyme cytochrome oxidase (Wharton \& Tzagoloff, 1967): the activity of this enzyme in the membrane preparations was approximately one-fifth that in protoplast lysates. Finally, the membranes were collected by centrifugation at $5300 \mathrm{~g}$ for $10 \mathrm{~min}$ at $4^{\circ} \mathrm{C}$ before being freeze-dried. Freeze-dried membranes were stored at $4{ }^{\circ} \mathrm{C}$ in a desiccator and used for lipid analyses within $2-3 \mathrm{~d}$. Freshly prepared membranes were used immediately for measurements of fluorescence polarization.

Extraction and analysis of fatty acids. Fatty acyl residues of acyl lipids in whole cells and crude plasma membranes were transmethylated to give fatty acid methyl esters by a modification of the method of Stoffel et al. (1959). Freeze-dried cells $(20 \mathrm{mg})$ or membranes $(15 \mathrm{mg})$ in a Pyrex tube closed with a screw cap were suspended in $1 \mathrm{ml}$ methanol containing $5 \%(\mathrm{w} / \mathrm{v}) \mathrm{HCl}$. The suspensions were maintained under an atmosphere of nitrogen gas and heated for $3 \mathrm{~h}$ in boiling water. After cooling to room temperature, distilled water $(1 \mathrm{ml})$ was added to each suspension and fatty acid methyl esters were extracted three times with light petroleum (b.p. $30-60^{\circ} \mathrm{C}$ ). Pooled extracts were dried overnight with anhydrous $\mathrm{Na}_{2} \mathrm{SO}_{4}$. The dehydrated extract containing fatty acid methyl esters was evaporated to dryness and the residue was dissolved in a small volume of diethyl ether. Fatty acid methyl esters were analysed by gas chromatography in a glass column $(3 \mathrm{~mm} \times 160 \mathrm{~cm})$ packed with Chromosorb WAW DMCS $(80 / 100$ mesh) coated with $15 \%(w / w)$ diethyleneglycol succinate at $165^{\circ} \mathrm{C}$. The injection port temperature was $210^{\circ} \mathrm{C}$ and the flow of nitrogen gas was $30 \mathrm{ml} \mathrm{min}^{-1}$. Fatty acid methyl esters were detected with a flame ionization detector at $200{ }^{\circ} \mathrm{C}$. The relative amount of each fatty acid methyl ester was calculated from the integrated area of each peak and expressed as a percentage of the total area of all peaks.

Extraction and estimation of ergosterol. Freeze-dried cells $(100 \mathrm{mg})$ or membranes $(30 \mathrm{mg})$ were suspended in distilled water $(1 \mathrm{ml})$, and ethanol $(9 \mathrm{ml})$ was added to the suspension to extract lipids (Letters, 1968). The suspension was mixed well, left for $24 \mathrm{~h}$ at $30^{\circ} \mathrm{C}$ and then centrifuged to separate the supernatant liquid. The pellet was subsequently treated twice with $10 \mathrm{ml}$ chloroform/methanol $(2: 1, \mathrm{v} / \mathrm{v})$ to extract remaining lipids. The combined extracts (chloroform/methanol extracts plus ethanol extract) were evaporated to dryness. This residue and the lipid-extracted residue were saponified by refluxing for $2 \mathrm{~h}$ in $35 \%$ (w/v) aqueous $\mathrm{KOH}(10 \mathrm{ml}$ ) (Shaw \& Jefferies, 1953). After cooling to room temperature, liberated sterols were extracted with diethyl ether. The extracts were evaporated to dryness and the residues were dissolved in chloroform for determination of the amount of free sterols and bound sterols by the Libermann-Burchard reaction as described by Hosono \& Aida (1974). Chloroform suspensions $(5 \mathrm{ml})$ containing sterols were mixed with $2 \mathrm{ml}$ acetic anhydride/sulphuric acid $(4: 1, v / v)$ and kept for $15 \mathrm{~min}$ at $18^{\circ} \mathrm{C}$. The sterol content was determined immediately by measuring the absorbance at $625 \mathrm{~nm}$ using ergosterol as the standard.

Extraction of proteins from crude plasma membranes. Freeze-dried membranes $(10 \mathrm{mg})$ in a glass-stoppered tube heated in boiling water were digested in $1.0 \mathrm{M}-\mathrm{NaOH}(2 \mathrm{ml})$ for $30 \mathrm{~min}$ to liberate proteins from the membranes. After cooling to room temperature, the suspension was centrifuged. The amount of protein in the supernatant was determined by the Lowry method with bovine serum albumin as the standard.

Extraction and analysis of lipids. Lipids were extracted successively with $10 \mathrm{ml}$ ethanol and $10 \mathrm{ml}$ chloroform/methanol $(2: 1, \mathrm{v} / \mathrm{v})$ from freeze-dried membranes $(100 \mathrm{mg})$. The combined extracts were evaporated to dryness and the residue was dissolved in $5 \mathrm{ml}$ chloroform/methanol $(2: 1, \mathrm{v} / \mathrm{v})$. In order to remove non-lipid materials

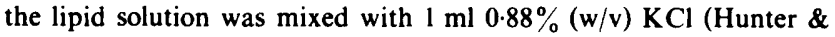
Rose, 1972). The mixture was separated into two phases by centrifugation at $2200 \mathrm{~g}$ for $5 \mathrm{~min}$. The upper phase was removed and discarded. The lower phase was evaporated to dryness and the amount of total lipids was determined gravimetrically. Phospholipid was determined by assaying the phosphorus content of the extract, using the method of Chen et al. (1956), after digestion of the lipid extracts with perchloric acid (Allen, 1940). Values for phosphorus contents were multiplied by 25 to give the total amount of phospholipids (Hossack \& Rose, 1976).

Fluorescence polarization measurements. To monitor the fluidity of lipid regions in the plasma membrane, 1,6-diphenyl 1,3,5-hexatriene (DPH) was used as a probe (Shinitzky \& Inbar, 1976; Shinitzky \& Barenholz, 1978). A solution of $2 \mathrm{mmol}$ DPH in tetrahydrofuran was 
Table 1. Fatty acid composition of whole cells and crude plasma membranes of $Z$. rouxii grown in YPD medium with or without $15 \% \mathrm{NaCl}$

Freeze-dried cells or membranes were transmethylated by heating in methanol containing $5 \%$

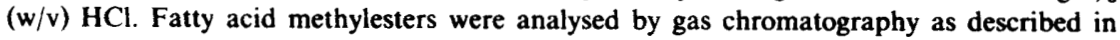
Methods. Values for unsaturation index were calculated as described by Kates \& Hagen (1964). Values shown are means \pm SD of at least four separate experiments.

\begin{tabular}{|c|c|c|c|c|}
\hline \multirow{3}{*}{$\begin{array}{l}\text { Fatty } \\
\text { acid }\end{array}$} & \multicolumn{4}{|c|}{ Fatty acid composition (percentage of total fatty acids) } \\
\hline & \multicolumn{2}{|c|}{ Whole cells } & \multicolumn{2}{|c|}{ Plasma membranes } \\
\hline & YPD & $\mathrm{YPD}+15 \% \mathrm{NaCl}$ & YPD & $\mathrm{YPD}+15 \% \mathrm{NaCl}$ \\
\hline $12: 0$ & $0.45 \pm 0 \cdot 19$ & $0.28 \pm 0.06$ & $0.16 \pm 0.05$ & $0.38 \pm 0 \cdot 10$ \\
\hline $14: 0$ & $1 \cdot 15 \pm 0.84$ & $0.45 \pm 0.16$ & $0.32 \pm 0 \cdot 18$ & $1.62 \pm 0.43$ \\
\hline $16: 0$ & $7 \cdot 88 \pm 0 \cdot 39$ & $7.63 \pm 0.26$ & $8.05 \pm 0.27$ & $7.78 \pm 0.38$ \\
\hline $16: 1$ & $11.53 \pm 0.80$ & $12.84 \pm 1.46$ & $11.59 \pm 1.81$ & $14.61 \pm 0.53$ \\
\hline $18: 0$ & $1.96 \pm 0.42$ & $1.07 \pm 0.39$ & $1.47 \pm 0.49$ & $0.93 \pm 0.27$ \\
\hline $18: 1$ & $31.06 \pm 1.81$ & $51 \cdot 90 \pm 2 \cdot 24$ & $32.63 \pm 0.89$ & $46.01+1.16$ \\
\hline $18: 2$ & $45.99 \pm 1 \cdot 20$ & $25 \cdot 82 \pm 1 \cdot 39$ & $46.27 \pm 0.62$ & $28.71 \pm 1.05$ \\
\hline \multicolumn{5}{|c|}{ Unsaturation } \\
\hline index & $1 \cdot 35$ & $1 \cdot 16$ & $1 \cdot 37$ & $1 \cdot 18$ \\
\hline
\end{tabular}

diluted 1000-fold with $50 \mathrm{~mm}$-Tris/ $\mathrm{HCl}$ buffer ( $\mathrm{pH} 7.4)$ containing $\mathrm{NaCl}(0.9 \%, w / v)$. For labelling, freshly prepared membranes were incubated for $30 \mathrm{~min}$ at $30^{\circ} \mathrm{C}$ with $3 \mathrm{ml}$ of the diluted DPH. The final protein concentration of the membranes was $20-80 \mu \mathrm{g} \mathrm{ml}^{-1}$. All fluorescence measurements were carried out at $30^{\circ} \mathrm{C}$. Fluorescence polarization measurements were made in a Shimadzu RF-5000 spectrofluorophotometer. DPH was excited at $340 \mathrm{~nm}$ while the emission was measured at $440 \mathrm{~nm}$. The measured fluorescence intensities were corrected for background fluorescence and light scattering from the unlabelled sample. The degree of fluorescence polarization, $P$, was calculated, according to Litman \& Barenholz (1982), from the equation

$$
P=\left(I_{\mathrm{Vv}}-I_{\mathrm{VH}} G\right) /\left(I_{\mathrm{VV}}+I_{\mathrm{VH}} G\right) \quad\left[G=I_{\mathrm{HV}} / I_{\mathrm{HH}}\right]
$$

where $I_{\mathrm{Vv}}$ and $I_{\mathrm{VH}}$ are the fluorescence intensities determined at vertical and horizontal orientations of the emission polarizer, respectively, when the excitation polarizer is set in the vertical position, and $I_{\mathrm{HV}}$ and $I_{\mathrm{HH}}$ are the fluorescence intensities determined at vertical and horizontal positions of the emission polarizer when the excitation polarizer is set horizontally. $G$ is a correction factor for the different response of the monochromators to vertically and horizontally polarized light.

\section{Results and Discussion}

\section{Fatty acid composition of whole cells and crude plasma} membranes

The fatty acid composition of whole cells and crude plasma membranes of $Z$. rouxii are shown in Table 1 . In common with most higher eukaryotic cells, the fatty acid composition of yeast total lipids shows a preponderance of fatty acids with a chain length of 16 and 18 carbon atoms although a variety of other fatty acids has been observed (Rattray, 1988). Of these fatty acids, the proportion of $C_{18: 1}$ increased considerably and that of
$\mathrm{C}_{18: 2}$ decreased by a corresponding amount both in whole cells and membranes when $Z$. rouxii was grown in medium with $15 \% \mathrm{NaCl}$. This is in agreement with a previous report that the percentages of cellular $C_{18: 1}$ acids increased and that of cellular $C_{18: 2}$ acids decreased when four strains of $Z$. rouxii were grown in medium containing $2 \mathrm{M}(12 \%, \mathrm{w} / \mathrm{v}) \mathrm{NaCl}$ (Watanabe \& Takakuwa, 1984). The relative proportions of $C_{16: 1}$ and $\mathrm{C}_{18: 0}$ acids increased and decreased, respectively, both in whole cells and in membranes of $Z$. rouxii grown in $15 \%$ $\mathrm{NaCl}$. The proportion of $\mathrm{C}_{16: 0}$ acids, both in whole cells and in membranes, was not influenced by the presence of $15 \% \mathrm{NaCl}$. There were also large changes in the proportions of the minor fatty acid components, $\mathrm{C}_{12: 0}$ and $\mathrm{C}_{14: 0}$ acids. When cells were grown in the presence of $15 \% \mathrm{NaCl}$, the proportions of $\mathrm{C}_{12: 0}$ and $\mathrm{C}_{14: 0}$ acids in whole cells decreased. In contrast, the relative amounts of $\mathrm{C}_{12: 0}$ and $\mathrm{C}_{14: 0}$ acids in membranes were approximately 2 and 5 times as high, respectively, as those of control cultures.

Changes in composition of acyl chains, such as unsaturation, length and branching, are thought to affect membrane fluidity. The degree of unsaturation can be expressed as the unsaturation index, defined by Kates \& Hagen (1964) as: $\Delta \mathrm{mol}^{-1}=1 \times(\%$ monoenes $) / 100+$ $2 \times(\%$ dienes $) / 100+3 \times(\%$ trienes $) / 100$. The values calculated by using this equation are shown in Table 1 . The unsaturation value of fatty acids in whole cells decreased from 1.35 to 1.16 and that of fatty acids in the membranes also decreased from 1.37 to 1.18 when cells were grown in the presence of $15 \% \mathrm{NaCl}$. This result might indicate that the plasma membrane is more rigid in the presence of a high concentration of salt in the 
Table 2. Ergosterol content of whole cells and crude plasma membranes of $Z$. rouxii grown in YPD medium with or without $15 \% \mathrm{NaCl}$

Free ergosterol was released from whole cells or plasma membranes by a conventional lipid extract procedure and bound ergosterol was released by saponification of the lipid-extracted residue. Liberated sterol was extracted with diethyl ether after alkaline hydrolysis, and then colorimetrically determined by the Libermann-Burchard reaction using ergosterol as the standard. Ergosterol contents are expressed as the amount (mg) per $\mathrm{g}$ dry wt of plasma membranes. ND, Not determined. Values shown are means \pm SD of at least four separate experiments.

\begin{tabular}{lcc}
\hline \hline Ergosterol & YPD & YPD $+15 \% \mathrm{NaCl}$ \\
\hline Whole cells & & \\
Free ergosterol & $6.1 \pm 0.7$ & $9 \cdot 3 \pm 1.2$ \\
Bound ergosterol & $0.6 \pm 0.1$ & $0.2 \pm 0.1$ \\
Plasma membranes & $5.5 \pm 0.4$ & $15 \cdot 7 \pm 1 \cdot 2$ \\
Free ergosterol & ND & ND \\
Bound ergosterol & \\
\hline
\end{tabular}

growth medium. Desaturation of fatty acids from $\mathrm{C}_{18: 1}$ to $\mathrm{C}_{18: 2}$ was inhibited by the presence of $15 \% \mathrm{NaCl}$ in the growth medium.

\section{Ergosterol content of whole cells and crude plasma membranes}

Sterols play an important role in determining the structural organization of biological membranes, which in turn influences such functions as permeability of solutes and the activities of membrane-bound enzymes (Lees et al., 1979; Yeagle, 1985). Sterols can be extracted from micro-organisms by two methods: (1) conventional lipid extraction procedures for sterols and/or sterol esters from cells, and (2) saponification to release bound sterols (Safe, 1973). In general, the major sterol of yeast has been reported to be ergosterol (Rattray, 1988). We examined the ergosterol content of whole cells and crude plasma membranes of $Z$. rouxii (Table 2). The amounts of free ergosterol increased both in whole cells and in membranes when cultures were grown in the presence of $15 \%$ $\mathrm{NaCl}$. The amount of free ergosterol from cells grown in medium with $15 \% \mathrm{NaCl}$ increased to approximately 1.5 times that of control cells, though the amount of bound ergosterol decreased to one-third of that from control cells. In the preparation of crude plasma membranes, only free ergosterol was found. The amount of free ergosterol in the membranes was more strikingly influenced by the presence of $15 \% \mathrm{NaCl}$ in the growth medium, increasing to approximately 3 times that of control cells. The increase in the amount of free ergosterol in the membranes might cause a decrease in membrane fluidity.
Table 3. Total lipid, phospholipid and protein contents of crude plasma membranes of $Z$. rouxii grown in YPD medium with or without $15 \% \mathrm{NaCl}$

Total lipids were determined gravimetrically after drying the lipid extract. Phospholipids were determined by assaying the phosphorus content of the lipid extract. Proteins were determined by the Lowry method after digesting plasma membranes with hot alkali. The amount of ergosterol is taken from Table 2. Contents are expressed as the amount (mg) per g dry wt of plasma membranes. Values shown are means \pm SD of at least four separate experiments.

\begin{tabular}{lcc}
\hline \hline & YPD & YPD $+15 \% \mathrm{NaCl}$ \\
\hline Total lipid & $340 \pm 95$ & $283 \pm 65$ \\
Phospholipid & $4 \cdot 1 \pm 0.9$ & $2 \cdot 3 \pm 0 \cdot 3$ \\
Protein & $84 \pm 8$ & $119 \pm 7$ \\
Ergosterol & $5 \cdot 5 \pm 0 \cdot 4$ & $15 \cdot 7 \pm 1 \cdot 2$ \\
Phospholipid/protein ratio & 0.05 & 0.02 \\
Ergosterol/phospholipid ratio & $1 \cdot 34$ & $6 \cdot 83$ \\
\hline \hline
\end{tabular}

Lipid, phospholipid and protein content of crude plasma membranes

The amounts of total lipid, phospholipid and protein in crude plasma membranes are shown in Table 3. The amount of phospholipids extracted from the membranes of cells grown in $15 \% \mathrm{NaCl}$ was lower than that from the membranes of control cells. However, the protein content of membranes of cells grown in $15 \% \mathrm{NaCl}$ was approximately 1.4 times higher than that of control cells. The ratio of phospholipid to protein in the membranes of cells grown in $15 \% \mathrm{NaCl}$ was less than half that in the membranes of control cells.

Sterols and phospholipids are the two major lipid constituents of eukaryotic biological membranes. Sterol has been reported to decrease the fluidity of the lipid phase of membranes (Demel \& de Kruyff, 1976). The microviscosity of biological membranes increases markedly with increases in the ratio of cholesterol to phospholipid (Russell, 1989). Changes in microviscosity might induce or alter various cellular functions that depend on the dynamics of the plasma membrane. The ratio of ergosterol to phospholipid in the membranes of cells grown in $15 \% \mathrm{NaCl}$ was approximately 5 times greater than that of control cells. This change suggests that membrane fluidity might decrease due to the presence of a high concentration of salt in the growth medium.

When grown in medium of high osmolarity, $Z$. rouxii accumulates glycerol within the cells as a compatible solute (Onishi, 1963). Under high-osmolarity growth conditions, it is possible that the plasma membrane might have to become more rigid in order to keep glycerol within the cells for the purpose of increasing the internal osmotic pressure. 


\section{Measurement of fluorescence polarization}

Chemical analyses of the lipid composition of the membranes indicated that they might be more rigid in $15 \% \mathrm{NaCl}$ compared with control cells. In order to measure the fluidity of the plasma membrane, the membranes were labelled with a fluorescence probe. A crude plasma membrane fraction was prepared from protoplasts immediately prior to each experiment, and fluorescence polarization was measured at $30^{\circ} \mathrm{C}$, the temperature at which the cells were cultured. The concentrations of membranes in sample solutions varied from $20-80 \mu \mathrm{g}$ protein $\mathrm{ml}^{-1}$, but the degree of fluorescence polarization was not affected. The fluorescence polarization value, $P$, of DPH in the membranes prepared from cells grown in YPD medium with or without $15 \% \mathrm{NaCl}$ was $0.308 \pm 0.024$ or $0.250 \pm 0.009$, respectively. The degree of fluorescence polarization, $P$, reflects the structural order of the membrane lipids, and the increased value of $P$ indicates that the membrane fluidity of cells grown in $15 \% \mathrm{NaCl}$ is less than that in control cultures. This is consistent with the results above, which suggested a decrease in membrane fluidity based on chemical analyses of lipids.

Under high-osmolarity growth conditions, $Z$. rouxii accumulates glycerol as a compatible solute within the cells in the exponential growth phase (Onishi, 1963). A characteristic of salt-tolerant yeasts might be the ability to change their membrane functions in order to keep compatible solutes within the cells in response to osmotic stress. Passive permeability properties are likely to be related to the content and composition of lipids, which also affects the fluidity of the plasma membrane. Beside the change in lipid composition, the protein content of membranes of cells of $Z$. rouxii grown in $15 \% \mathrm{NaCl}$ was higher than that of control cells. An active glycerol transport mechanism regulated by water activity has been found in the yeast Debaryomyces hansenii (Adler et al., 1985) and in Z. rouxii itself (Zyl et al., 1990), while yeasts such as $S$. cerevisiae and Candida utilis take up glycerol by passive diffusion (Gancedo et al., 1968; Cooper, 1982). The active transport mechanism might be controlled to accumulate glycerol within cells under osmotic stress. The action of plasma membrane ATPase has been reported to affect several stress tolerances of $S$. cerevisiae and Schizosaccharomyces pombe (Panaretou \& Piper, 1990).

\section{References}

AdLer, L., Blomberg, A. \& Nilsson, A. (1985). Glycerol metabolism and osmoregulation in the salt-tolerant yeast Debaryomyces hansenii. Journal of Bacteriology 162, 300-306.
Allen, R. J. L. (1940). The estimation of phosphorus. Biochemical Journal 34, 858-865.

Ben-Amotz, A. \& Avron, M. (1983). Accumulation of metabolites by halotolerant algae and its industrial potential. Annual Review of Microbiology 37, 95-119.

Brown, A. D. (1978). Compatible solutes and extreme water stress in eukaryotic micro-organisms. Advances in Microbial Physiology 17, 181-242.

COOPER, T. G. (1982). Transport in Saccharomyces cerevisiae. In The Molecular Biology of the Yeast Saccharomyces. Metabolism and Gene Expression, pp. 399-461. Edited by J. N. Strathern, E. W. Jones \& J. R. Broach. Cold Spring Harbor, NY: Cold Spring Harbor Laboratory.

Chen, P. S., JR, Toribara, T. Y. \& Warner, H. (1956). Microdetermination of phosphorus. Analytical Chemistry 28, 1756-1758.

CsonKa, L. N. (1989). Physiological and genetic responses of bacteria to osmotic stress. Microbiological Reviews 53, 121-147.

Demel, R. A. \& De KRUYFF, B. (1976). The function of sterols in membranes. Biochimica et Biophysica Acta 457, 109-132.

Edgley, M. \& Brown, A. D. (1983). Yeast water relations: physiological changes induced by solute stress in Saccharomyces cerevisiae and Saccharomyces rouxii. Journal of General Microbiology 129, 3453-3463.

Gadd, G. M., Chudek, J. A., Foster, R. \& Reed, R. H. (1984). The osmotic responses of Penicillium ochro-chloron: changes in internal solute levels in response to copper and salt stress. Journal of General Microbiology 130, 1969-1975.

Gancedo, G., GANCEDO, J. M. \& Sols, A. (1968). Glycerol metabolism in yeasts. Pathways of utilization and production. European Journal of Biochemistry 5, 165-172.

HagemanN, M., ERdmann, N. \& Wittendurg, E. (1987). Synthesis of glucosylglycerol in salt-stressed cells of the cyanobacterium Microcystis firma. Archives of Microbiology 148, 275-279.

Higgins, C. F., Cairney, J., Stirling, D. A., Sutherland, L. \& Booth, I. R. (1987). Osmotic regulation of gene expression: ionic strength as an intracellular signal? Trends in Biochemical Sciences 12 , 339-344.

Hocking, A. D. (1986). Effects of water activity and culture age on the glycerol accumulation patterns of five fungi. Journal of General Microbiology 132, 269-275.

Hosono, K. \& AIDA, K. (1974). Lipid composition of Saccharomyces cerevisiae defective in mitochondria due to pantothenic acid deficiency. Journal of General and Applied Microbiology 20, 47-58.

Hosono, K. \& HaHN-HÄGERDAL, B. (1986). Separation of yeast protoplasts from membrane ghosts using an aqueous two-phase system. Biochimica et Biophysica Acta 855, 189-192.

HossACK, J. A. \& ROSE, A. H. (1976). Fragility of plasma membranes in Saccharomyces cerevisiae enriched with different sterols. Journal of Bacteriology 127, 67-75.

HUNTER, K. \& ROSE, A. H. (1972). Lipid composition of Saccharomyces cerevisiae as influenced by growth temperature. Biochimica et Biophysica Acta 260, 639-653.

Jennings, D. H. (1984). Polyol metabolism in fungi. Advances in Microbial Physiology 25, 149-193.

KATES, M. \& HAGEN, P. O. (1964). Influence of temperature on fatty acid composition of psychrophilic and mesophilic Serratia species. Canadian Journal of Biochemistry 42, 481-488.

Lees, N. D., Bard, M., Kemple, M. D., HaAK, R. A. \& Kleinhans, F. W. (1979). ESR determination of membrane order parameter in yeast sterol mutants. Biochimica et Biophysica Acta 553, 469-475.

Le Rudulier, D., Strom, A. R., Dandekar, A. M., Smith, L. T. \& VALENTINE, R. C. (1984). Molecular biology of osmoregulation. Science 224, 1064-1068.

LetTers, R. (1968). Phospholipids of yeasts. In Aspects of Yeast Metabolism, pp. 303-319. Edited by A. K. Milles. Oxford: Blackwell Scientific Publications.

LitMan, B. J. \& BarenHolz, Y. (1982). Fluorescent probe: diphenylhexatriene. Methods in Enzymology 81, 678-685.

MeIKLE, A. J., Reed, R. H. \& GADD, G. M. (1988). Osmotic adjustment and the accumulation of organic solutes in whole cells and protoplasts of Saccharomyces cerevisiae. Journal of General Microbiology 134, 3049-3060. 
ONISHI, H. (1963). Osmophilic yeasts. Advances in Food Research 12 , 53-94.

Panaretou, B. \& Piper, P. W. (1990). Plasma-membrane ATPase action affects several stress tolerances of Saccharomyces cerevisiae and Schizosaccharomyces pombe as well as the extent and duration of the heat shock response. Journal of General Microbiology 136, 17631770.

RatTray, J. B. M. (1988). Yeasts. In Microbial Lipids, vol. 1, pp. 555697. Edited by C. Ratledge \& S. G. Wilkinson. London: Academic Press.

Reed, R. H., Borowitzka, L. J., Mackay, M. A., Chudek, J. A., Foster, R., Warr, S. R. C., MOORe, D. J. \& Stewart, W. D. P. (1986)., Organic solute accumulation in osmotically stressed cyanobacteria. FEMS Microbiology Reviews 39, 51-56.

Reed, R. H., Chudek, J. A., Foster, R. \& Gadd, G. M. (1987). Osmotic significance of glycerol accumulation in exponentially growing yeasts. Applied and Environmental Microbiology 53, 21192123.

Russell, N. J. (1989). Functions of lipids: structural roles and membrane functions. In Microbial Lipids, vol. 2, pp. 279-365. Edited by C. Ratledge \& S. G. Wilkinson. London: Academic Press.

SAFE, S. (1973). The effect of environment on the free and hydrosoluble sterols on Mucor rouxii. Biochimica et Biophysica Acta 326, 471-475.

Shaw, W. H. C. \& JefFeries, J. P. (1953). The determination of ergosterol in yeast. II. Determination by saponification and ultraviolet absorption spectroscopy. Analyst 78, 514-519.
ShinItZKy, M. \& INBAR, M. (1976). Microviscosity parameters and protein mobility in biological membranes. Biochimica et Biophysica Acta 433, 133-149.

ShinitZKy, M. \& BARENHOLZ, Y. (1978). Fluidity parameters of lipid regions determined by fluorescence polarization. Biochimica $\boldsymbol{e t}$ Biophysica Acta 515, 367-394.

Singer, S. J. \& Nicolson, G. L. (1972). The fluid mosaic model of the structure of cell membranes. Science 175, 720-731.

Stoffel, W., Chu, F. \& Ahrens, E. H., JR (1959). Analysis of longchain fatty acids by gas-liquid chromatography. Micromethod for preparation of methyl esters. Analytical Chemistry 31, 307-308.

WATANABE, Y. \& TAKAKUWA, M. (1984). Effect of sodium chloride on lipid composition of Saccharomyces rouxii. Agricultural and Biological Chemistry 48, 2415-2422.

Wharton, D. C. \& Tzagoloff, A. (1967). Cytochrome oxidase from beef heart mitochondria. Methods in Enzymology 10, 245-250.

Yancey, P. H., Clark, M. E., Hand, S. C., Bowlus, R. D. \& Somero, G. N. (1982). Living with water stress: evolution of osmolyte systems. Science 217, 1214-1222.

YeaGle, P. L. (1985). Cholesterol and the cell membrane. Biochimica et Biophysica Acta 822, 267-287.

van ZYL, P. J., Kilian, S. G. \& PrioR, B. A. (1990). The role of an active transport mechanism in glycerol accumulation during osmoregulation by Zygosaccharomyces rouxii. Applied Microbiology and Biotechnology 34, 231-235. 